\title{
Environmental Refugees: Consequences and Policies from a Western Perspective
}

\author{
ALAN E. NASH \\ Department of Geography, Concordia University, 1455 de Maisonneuve Blvd. West, Montreal, Quebec, H3G 1M8, Canada
}

(Received 16 November 1998)

\begin{abstract}
Using Canada as an example, this paper argues that the phenomenon of the environmental refugee poses a series of important public policy issues for countries of resettlement. Arguing that Canada has an obligation to aid environmental refugees, for reasons of both self-interest and self-sacrifice, the paper then explores those reasons that have, so far, prevented Canada acting on these obligations. These lie, the paper argues, in a conjunction of both present public opinion and government practice. It is therefore in these realms that action to remove impediments to policy change must now occur.
\end{abstract}

Keywords: Environmental refugees, Public policy, Canada

\section{INTRODUCTION}

There has been a growing concern about the topic of "environmental refugees" in recent years, sparked by the parallel developments of a growing public concern for the environment and news of repeated ecological crises across the globe: of which, perhaps the famines in the Horn of Africa are only the latest examples.

However, this concern has not translated itself into any meaningful debate about the policy issues the problems of "environmental refugees" raise. Therefore, after defining this term, the following paper attempts to consider some of the policy issues and problems involved: first, by considering the nature of Canada's obligations towards environmental refugees; and second, by examining the significance of the phenomenon of environmental refugees for Canadian public policy. The paper then attempts to answer why Canada has yet to deal with either the obligations or the policy issues it now faces. The impediments to action are located, as will be seen, in both the realms of public opinion and government behaviour and it is there that the paper concludes that future policy initiatives on behalf of the environmental refugee lie.

\section{CANADA'S OBLIGATIONS TOWARDS ENVIRONMENTAL REFUGEES}

Towards a Definition of the Term

"Environmental Refugee"

Under the terms of the International Convention Relating to the Status of Refugees, refugees, or 
"Convention refugees" as they are more formally termed, are defined as any person who

owing to well-founded fear of being persecuted for reasons of race, religion, nationality, membership of a particular social group or political opinion, is outside the country of his origin and is unable or, owing to such fear, is unwilling to avail himself of the protection of that country; or... owing to such fear, is unwilling to return to it (Article 1(A) (2) para. 2; United Nations 1983: 11).

Since the enactment of the Convention in 1951, the refugee problem has changed from being mainly a European phenomenon to a Third World dilemma, and has grown enormously. Thus, in 1984 the Office of the United Nations High Commissioner for Refugees (UNHCR) estimated there were 10.8 million Convention refugees worldwide; by 1992 it estimated there were over 18 million (United Nations High Commissioner for Refugees 1984: 24-25; 1993: 3).

The factors causing this growth in refugee flows and its changing distribution are, to quote the United Nations Group of Governmental Experts on International Co-operation to Avert New Flows of Refugees, "a result of a number of complex and often interrelated political, economic and social problems related to, and influenced by, the overall international situation" (United Nations 1986, paragraph 63).

In one very useful categorization, Zia Rizvi has sought to divide the factors responsible for refugee movements in general into three groups as follows: "primary factors", which include those violations of human rights enumerated in the 1951 Convention that are direct grounds upon which to claim refugee status, as in the case of the 18 million noted above; "secondary factors", such as civil war, that are partly enumerated in the 1969 Convention adopted by the Organization of African Unity and becoming more widely accepted by the international community as an additional basis on which to define a broader refugee status; and, finally, "auxiliary factors" which, Rizvi argues, are newly recognized and considered excluded from traditional international concepts of refugee status. These include economic, demographic and ecological factors (Rizvi, 1988: 110).
According to Rizvi, such "auxiliary factors", or "root causes" as they are more generally known, are increasingly dominating the refugee scene. They will continue to do so for two reasons: first, through an indirect and complex causal relationship in which such root causes result in persecution on the five grounds defined in the 1951 Convention; second, through the direct generation of mass movements of people fleeing economic, demographic or ecological crises in their own countries in order to seek desperately-needed succour elsewhere.

The definition of the term "ecological" or "environmental refugee" is, of course, one that has been widely discussed by a variety of scholars (see, for example, Kritz, 1990; McGregor, 1993). Since it is not the role of this paper to review or to critique that body of work but rather to show how public policy has reacted to the existence of the idea of the environmental refugee as a phenomenon, it is sufficient to adopt here the definition of the most widely-read author in government and non-governmental organization circles, that of Jodi Jacobson. Taking as her definition those individuals who have been forced to leave their country of origin due to the deterioration of their surrounding environment which no longer provides basic elements needed to sustain life, she has estimated that as many as 10 million migrants can be considered environmental refugees (Jacobson, 1988: 6). Such a figure nearly doubles the world's total number of refugees and, of course, would significantly increase the size of the problem to be faced by the global community if such a definition was officially accepted.

But the important point here is that it has not yet been. Rizvi's "auxiliary factors" may trigger movement because of a denial of rights that are guaranteed by the International Covenant on Economic and Social Rights, but environmental or economic causes in themselves are not recognized by the 1951 Convention as ones defining refugee status (Hathaway, 1991: 92-97). Thus, environmental or economic migrants cannot earn either the official designation of "Convention refugee" or the protection from refoulement and financial assistance that this situation affords. 
Nevertheless, their movement challenges the global community, not only because they are a growing phenomenon, not only because they lie outside the traditional framework that the world has developed to resolve refugee issues (Rizvi, 1988: $110,113)$, but also because their plight and how it is dealt with ultimately affects us all.

\section{Canada's Obligations Towards Environmental Refugees}

Having provided a working definition of the phenomenon of environmental refugees and indicated the dilemma of their position (on the one hand, their pressing need for assistance but, on the other, their current lack of international recognition), it is necessary to examine the issue of Canada's obligations, if any, towards them. This will be done here by analysing the two basic questions that the dilemma of environmental refugees pose for a Western country, traditionally viewed as one of resettlement. First, why should Canada be concerned about the plight of such people; second - if it appears that Canada should be concerned - what, in terms of practical policy, can this country do?

The first question - should Canada be concerned about the existence, and growing number of environmental refugees - can be dealt with on two levels: using what the Canadian philosopher and refugee scholar, Howard Adelman (1988), writing about the case of refugees in general, has recently called the principles of "self-sacrifice" and "self-interest". Using the principle of self-sacrifice, it could be argued on a moral or ethical level that, whoever we are and wherever we may be, we should be concerned with the plight and suffering of other people, however far afield they are, because they are a part of our shared humanity - a view perhaps best expressed by the metaphysical Anglican cleric John Donne when he wrote that "any man's death diminishes me because I am a part of mankind". Indeed, as Adelman himself has argued

At its limit, self-sacrifice entails the sacrifice of the individual out of universal obligation to all mankind. Some call it charity when the self-sacrifice is limited to a limited portion of one's personal bounty. Rawls and Walzer call their principle mutual aid since the principle of helping strangers who happen to cross your path is qualified even further by minimal risk to oneself (1971: 114; 1983: 45). Nevertheless, the principle of self-sacrifice, the principle of charity, and the principle of mutual aid all proceed from a source opposite to self-interest - even if self-interest qualifies them to different degrees - the duty to sacrifice self for the benefit of others (Adelman, 1988: 84 ; author's emphasis).

The alternative principle of self-interest relies, at least in its general sense, when it can be applied to all refugees, on the fundamental principle of justice that every individual is entitled to the protection of a state in a territory where they can earn the necessities of life. As Adelman has argued

States that share that principle must collectively extend that principle to those who are the victims of states that do not live up to the principle. If they do not accept the principle as a universal obligation, that is, if they do not apply the principle to all mankind, they would not be entitled to claim that belief as a principle of justice. It is precisely by making their particular beliefs a universal obligation of all and to all mankind that self-interest is built into a principle of justice (ibid.).

He extends this reasoning by arguing that a concern for the preservation of international order - surely the concern of most nation states - derives directly from this principle. Thus

it is in the self-interest of states that adopt the duty to protect their individual members to extend that protection to individuals outside the protection of any state, lest these stateless individuals create disorder in their quest for the necessities of life and for protection and thereby threaten the international order (ibid.).

Otherwise, as Adelman has noted elsewhere, "the nations will de facto encourage the stateless to take explosive measures to demonstrate the hazards of their statelessness" (Adelman, 1991a: 19).

Beyond these general arguments, self-interest is also engaged in the specific case of environmental refugees because of the obvious point that we are all part of one global interacting environmental system. This is, first, because the movement of environmental refugees from areas that can no longer sustain habitation may increase the pressures of population and promote accelerated decay in the surrounding territories to which they have moved, 
and so may ultimately prompt further migrations ever further afield. Second, because of the complex interrelatedness of the world's ecosystem, a deterioration in one part of that system may ultimately have environmental ramifications across the whole global system. In this way, Canada is affected by practices far outside its borders: for both the initial circumstances which caused the environmental refugees to move and the stresses that their subsequent movements place upon other areas will affect the global ecosystem of which this country is a part. Thus, for example, Third World deforestation not only partly influences local populations to migrate to neighbouring locales where they, in turn, put additional stresses upon the local environment, but also via the related phenomena of global warming and sea level increase, will have profound effects upon the ability of Canada's own environment to support its own population.

This elaborate chain of events may appear surprising but a brief consideration of the processes involved clearly demonstrates the connections and, moreover indicates that they are well-reported in documentation known to Canadian policy makers. Thus, it is well-known that the so-called "greenhouse gases" - methane, nitrous oxide, ground-level ozone, chlorofluorocarbons and, principally, carbon dioxide - trap the warmth of the sun before it is radiated out into space by the earth: without this "greenhouse effect", the earth's average temperature would drop to about $-18^{\circ} \mathrm{C}$. Just as importantly, increasing amounts of greenhouse gases in the atmosphere pose what the Brundtland Commission identifies as a "threat to life-support systems" because of their ability to trap increasing proportions of the sun's warmth (Environment Canada 1990: 97-98; World Commission on Environment and Development, 1987: 33).

Estimates produced by the Intergovernmental Panel on Climate Change (IPCC), established under the auspices of the World Meteorological Organization and the United Nations Environment Programme, suggest that for thousands of years before the Industrial Revolution, the amount of carbon dioxide in the atmosphere did not exceed 280 parts per million (ppm). Since then, however, concentrations have reached $350 \mathrm{ppm}$ and are increasing at $1.8 \mathrm{ppm}$ a year. In addition, the IPCC estimates that concentrations of the other greenhouse gases are also increasing. Their projections suggest that such trends, if continued unabated, will result in an increase in global mean temperatures of between $2.6^{\circ} \mathrm{C}$ and $5.8^{\circ} \mathrm{C}$ over the next century, and increases in sea level - due to the melting of the ice caps and, principally, to the expansion of water held in the oceans - of between 0.3 and $1.0 \mathrm{~m}$ over the same period (MacNeill et al., 1991: 11, 76).

The result of such changes, both directly and through their consequent effects on world climate patterns, "would be disaster" according to Linda Starke in her recent book Signs of Hope. She observes that

[p]rime agricultural areas could suddenly find that crops will no longer thrive there. After decades of investment, irrigation systems could be useless, or in the wrong place. Tropical systems are expected to increase in number and severity. Low-lying delta regions and islands are particularly threatened by the expected global sea-level rise. In fact, the President of the Maldives ... recently invited the Commonwealth Heads of Government to hold their meeting in the Maldives in 2030, but warned that it might have to be under water (Starke, 1990: 20).

Carbon dioxide, as the principal greenhouse gas, has the leading role in these changes. Indeed, carbon dioxide emission is regarded by the IPCC as responsible for over $50 \%$ of the enhanced greenhouse effect seen not only in the past but also in its projections of future trends (Grubb, 1990: 8-9). This gas has a variety of sources but, according to the best available estimates, the main sources of carbon dioxide emissions currently are: (1) fossil fuel combustion, which produces an estimated 6 billion tonnes of carbon annually; (2) the cutting and burning of forests and other land-use changes, which produce between 0.9 and 2.5 billion tonnes of carbon per year; and, (3) cement manufacture (World Commission on Environment and Development, 1987: 33; Grubb, 1990: 17-19; Starke, 1990: 24).

Thus it is that deforestation - both in the developed and the developing world - contributes, 
as one of the leading sources of carbon dioxide emission, to the increase of the main greenhouse gas in the atmosphere and thereby to global warming with its associated complex climate changes and sea-level increase: phenomena that because of their global impact will have effects on every country of the world. Of course, the case of the Maldives serves as a remarkable example of what might happen, but the possible impact of these phenomena on countries such as Canada, while perhaps less severe, should not be overlooked.

Importantly, this point is, in fact, recognized in the Canadian federal government's recent Green Plan where the possible effects of global warming are shown on a map of Canada and listed as follows:

(1) northern British Columbia: "warmer temperatures could cause changes in fish populations"; (2) central Alberta: "changes in rainfall patterns could increase drought in the Prairies"; (3) southern Saskatchewan: "water supplies in Southern Canada could decline significantly"; (4) central Saskatchewan: "soil degradation and erosion of prairie land may increase due to moisture loss"; (5) Ontario: "Great Lakes winter ice system may disappear"; (6) northern Quebec: "forest region could shift northward, with deciduous trees growing as far north as James Bay"; (7) Gulf of St. Lawrence: "many coastal areas could be flooded"; (8) Nova Scotia: "inshore fisheries season could be extended"; (9) Southern Ontario: "snow seasons could disappear" (Environment Canada, 1990: 99).

James MacNeill (a Canadian, and Secretary to the Brundtland Commission) and his co-authors add that "[g]lobal warming will also increase the probability of severe droughts in the agricultural heartlands of ... North America" and highlight southern British Columbia on their map entitled "Coastal areas vulnerable to sea-level rise" (MacNeill et al., 1991: 15-16). On a smaller scale, future problems appear similarly compelling: as but one example, the Canadian federal government's Green Plan notes that a one metre rise in sea level would affect more than 250 houses in Charlottetown, Prince Edward Island, and would contaminate local ground water sources with sea water (Environment Canada, 1990: 99).

From this discussion it appears that considerations of both self-interest and self-sacrifice should compel Canada to be concerned with the plight of environmental refugees. It is because both motives are involved in this case that the argument can be put this strongly. Otherwise, Canada's record, only in terms of self-sacrifice - as measured by its current overseas aid budget or Convention refugee programmes - is not one that would lead us to suggest that motives of self-sacrifice on their own would be sufficient to prompt Canada into extensive action on behalf of environmental refugees. However, the additional threat of large numbers of people spontaneously arriving on Canada's borders due to the collapse of their environment, and the effects of that collapse on the ability of the global environment to sustain Canada's ecosystems must surely prompt a government response - if only out of a sense of responsibility to the Canadian people. The principle of self-interest demands it.

\section{THE SIGNIFICANCE OF ENVIRONMENTAL REFUGEES FOR CANADIAN PUBLIC POLICY}

Thus far, this paper has argued that environmental refugees ought, in theory, to be aided by countries such as Canada for motives of both self-interest and self-sacrifice. The various arguments of a number of philosophers, political scientists and environmentalists would concur with such a viewpoint. If this is indeed the case, then it is necessary to consider how such countries could address the practical and dayto-day nature of meeting these obligations; to examine what significance environmental refugees could have in the formulation of a country's public policy towards immigration issues.

In doing so, it is fortunate that we already have some benchmarks for Canada's possible policy options in this regard in its behaviour towards another group of international involuntary migrants - the Convention refugees.

\section{Canada's Traditional Response to Convention Refugees}

It is well-known that Canada has traditionally been receptive to the plight of the "political refugee". 
Internationally recognized in the award of the Nansen Medal to Canada, this tradition has become a shibboleth of Canadian government statements and a talisman of Canadian public opinion regarding this issue (Hawkins, 1989).

After the end of the Second World War it becomes possible to examine in detail the behaviour of Canada towards "political", or Convention, refugees. Indeed, this periodization coincides with increased activity in this field: the establishment of Canada's Convention Refugee Class, the Designated Classes and its humanitarian programmes (the latter two categories, as elaborated below, being reserved for those asylum seekers the government sought to aid outside formal UNHCR definitions), the increasing number of refugees worldwide seeking asylum and the development of international responses following the 1951 Convention (Dirks, 1977; Richmond, 1994).

The data indicate that 332,892 refugees and beneficiaries of humanitarian programmes landed in Canada between 1947 and 1980. The predominant components of this movement were the postwar flow from Europe between 1947 and 1957 (some 186,000 individuals) and the Indochinese Refugee Programme of $1979-1980(60,049)$. These two movements accounted for 74 percent of the total flow between 1947 and 1980. Over the period 19811987, we see a quickening of the pace of admission, reflecting a worldwide growth in refugee numbers discussed earlier. Thus, 140,869 individuals were admitted or landed in Canada under refugee and humanitarian programmes. Of this total, 116,775 were admitted as refugees (Convention Refugees and members of the Designated Classes, either government or privately-sponsored) and 24,094 (or 17 percent of the total) under the humanitarian programmes (Employment and Immigration Canada, 1982; 1987a,b)

At first sight, at least, these data indicate Canada's clear willingness to become involved in providing asylum to large numbers of people (almost half a million over the period 1947-1987), to meet its international obligations towards Convention refugees and (by creating additional categories of "refugee", such as the Designated Classes and the humanitarian programmes) demonstrates its flexibility in meeting the needs of those who find themselves in "quasi-refugee" situations or who have difficulty in getting their formal status recognized (Hawkins, 1989; Richmond, 1994). Using this behaviour as a model of response, environmental refugees might indeed expect Canadian policy towards them to be at least as sensitive as it has been towards other types of refugees.

\section{Possible Canadian Public Policy Responses}

Having shown that the extent of Canada's response to those that fit the traditional definitions of "refugee" indicates, at least on a prima facie level, a general potential to become committed to those it deems to be in need, it is now useful to consider the range of policy options that Canada has available with regard to the specific case of environmental refugees.

These fall under three broad heads: first, by recognizing the plight of environmental refugees by including them within the criteria of those eligible for refugee assistance; second, dealing with the root causes of their plight; and, third, promoting an international response.

In terms of the first, Canada could take rapid and imaginative steps to include environmental refugees within the definition of those it treats as refugee and humanitarian cases. The majority of such cases currently admitted to Canada are not, in any case, Convention refugees but rather enter under one of this country's humanitarian programmes. These programmes are targeted at "quasi-refugees", individuals whom Canada would like to help but who fall outside the strict definitions of the 1951 Convention definition (Adelman, 1991b: 210-217). To do this, the 1976 Immigration Act allowed for the establishment, by regulation, of the Special Measures programmes and the Designated Classes, an authority which has been used extensively by the government since then (Nash, 1989: 39-41). Indeed, it is estimated that 75 percent of Canada's entire refugee and humanitarian landings fall into these 
categories. Special Measures programmes have, for example, assisted many Poles to reach Canada, while the Indochinese Designated Class facilitated the entry of thousands of Vietnamese boatpeople into this country during the late 1970s and early 1980s (Hathaway, 1988). This being the case, it is clear that Canada could easily extend its assistance and protection to environmental refugees - beyond the additional and necessary policies of expanding in situ humanitarian assistance to affected areas in order to counter massive potential movements of such people - simply by creating another humanitarian landing program to accommodate them. Having said this, it is worth adding that because Canada would only be able to admit a limited number of such individuals, not only because Canada obviously cannot provide a home for all the world's environmental refugees but also because of the ever-present fear of engendering a public backlash against immigration, the country's attention would be best focused upon specific areas of the world where such action could achieve the most effect.

Research is urgently needed to identify such "strategic" areas but one example can be quoted here to illustrate the argument. If it is the case that human-induced environmental degradation in parts of the Himalayan highlands in Bhutan is responsible for the increased intensity and severity of flooding further downstream in Bangladesh (Karan, 1987: 15), one possible solution to the problem might be for Canada to provide resettlement opportunities for the small Himalayan population involved. This would not only immeasurably improve the lot of these people but also would remove the threat of future difficulties for the far larger populations of those parts of Bangladesh that stood to be flooded if degradation continued unabated.

To provide more than mere alleviation, Canada must, of course, begin to address the root cause of the problem - to address one of Rizvi's "auxiliary factors" that cause refugee movements - the degradation of the environment that has and will occasion the production of environmental refugees. In this regard, Canada should consider, for example, policies such as the elimination of its overseas aid projects (run by the Canadian International Development Agency) that are environmentally unsound and, instead, the creation of "sustainable development aid"; the provision of "clean up" project funding for Third World and Eastern European countries that need it; the promotion and provision of environmental education in countries where it is required; the promotion and provision of equipment that encourages sustainable practices - such as, for instance, solar ovens in refugee camps in Africa or the provision of non-CFC refrigerant technology to China; the encouragement of research and development in environmentally-sound endeavours that can then be used to benefit the wider world community; and, "early warning" research to pinpoint regions of the world that might be affected mostly by future changes in the environment and where the potential for refugee flows might be greatest unless action is taken.

Canada cannot solve the plight of environmental refugees on its own, and for this reason the final set of initiatives must include those of international response and burden-sharing - responses that require a world commitment but in which, obviously, Canada might be able to play more than its part through exercising its traditional leadership in humanitarian issues or by galvanizing the many world bodies of which it is a member. Policies in this respect include the renegotiation of the 1951 Convention refugee definition so that environmental refugees might be eligible for the protection and assistance of the UNHCR and all countries party to such an agreement. Interestingly, the noted legal scholar Guy Goodwin-Gill has recently argued that the current meaning of the principle of nonrefoulement "must now be understood beyond and apart from its formulation in article 33 of the [1951] Convention". He continues, "[t]he range of relevant situations could arguably encompass all in distress, whether from natural disaster, from human misadventure, or so-called man-made disaster" (Goodwin-Gill, 1991: 28).

Other possible international responses that Canada could champion include the rejection by 
multilateral bodies, such as the World Bank and the International Monetary Fund, of non-sustainable development projects; the linking of foreign policy and external trade issues with not only humanitarian issues, but also with environmental practice; and, lastly, a resolution of the Third World debt crisis before many of the nations involved have destroyed all their natural resources in order simply to service their huge loans.

Lastly, in terms of domestic response, it is important not to forget that Canada's own treatment of its environment has to be considered. This is not only because the overconsumption of resources and production of pollution by Canadians threaten the world's fragile ecosystem but because the pressures of Canada's growing population itself threatens both in a real and a perceived sense - the sustainability of the Canadian environment and therefore, perhaps ironically, its ability to provide a home for Canadians and a safe haven for those fleeing the collapse of environments elsewhere in the world. Indeed, it is to this irony that discussion must now turn.

\section{THE IMPEDIMENTS TO PROACTIVE CANADIAN PUBLIC POLICY ON ENVIRONMENTAL REFUGEES}

Having argued that Canada has traditionally displayed a generosity towards those in need, and reviewed the nature of the policy options open to Canada in order to meet the needs of the environmental refugee, it is now necessary in the concluding section of this paper to ask why - given all these arguments - it is that Canada has chosen to ignore their plight. The thesis to be advanced here is that, in brief, through an unusual conjunction of interests and timing, Canadian public opinion and government policy have coalesced into an attitude of indifference towards those who find themselves to be environmental refugees.

In terms of Canadian public opinion, the reasons for this change are diverse, but - as the above irony noted - have some of their roots in a concern for the environment itself. The history of the Green Movement in Canada has certainly been a distinguished one, but it has served to forge the powerful equation that population growth equals environmental decline in many people's minds (Fincher, 1994). As long ago as 1976, the report Human Settlement in Canada remarked that

[t]he majority of urban growth in Canada is taking place in three of the nation's most fertile areas: south-central Ontario, the St. Lawrence lowlands in Quebec, and the Lower Mainland in British Columbia. Together these three areas contain 24 million acres of the finest agricultural land in Canada. Much of it is unique because of mild climate, good rainfall, and excellent soil. There can be no doubt that significant tracts of this land are threatened by the expansion of settlement (Canadian Habitat Secretariat, 1976: 52).

It does not take a great extension of such warranted concerns to arrive at vague Malthusian fears concerning over-population or - more importantly - to arrive at the view that immigration itself can become the agent fuelling population growth and thereby poses an environmental threat to Canadians (Fincher, 1988: 512). Certainly, a number of right-wing groups in Canada have successfully sought to weld the public's sympathy with action on the environment to an anti-immigration platform. As Regier and Bales have observed, in explaining an official reticence to examine the effects of growing numbers of people in Canada,

the population question is tied directly to immigration, an activity with which many environmentalists are historically sympathetic. To demonstrate the deleterious effect of expanding population numbers on the health of terrestrial and aquatic ecosystems, and to implicate immigrants, may attract an undesirable group of supporters - the so-called "red necks" (1991: 2).

Already such concerns have begun to surface in fora as various as the Canada Employment and Immigration Advisory Council, where we are told that "it would be worthwhile in a proactive sense to delve deeper into the issue (of environment and immigration) before the perception settles that immigrants damage the environment" (Canada Employment and Immigration Advisory Council, 1991: 31), or the anti-growth lobby group known as Zero Population Growth which notes that "our social and 
environmental problems will worsen as long as we continue to allow a rate of high migration ... more people means more severe problems" (1991: 2).

Undoubtedly, if this challenge is to be met, amongst many other steps, not only will existing environmental educational programmes for Canadians have to be made effective but also similar programmes must be established for new immigrants, renewed attention must be given to the issues of the country's ultimate carrying capacity under a range of technologies, and regional policies for immigration within Canada must be considered.

The second principal root of increasing public indifference lies, somewhat contradictorily given what has just been said, in the general decline of concern for environmental issues in Canada. The publication of the federal Green Plan probably marked the high point of that interest. Since then, the environment has fallen from the public's leading concern as unemployment, economic recession and debt reduction have dominated attention - a fact clearly sensed by the current Liberal administration of Jean Chretien, which has gradually lowered the power and finances of Environment Canada and its ministry (Greenspon, 1995).

The third root lies in the significant proportion of the Canadian public that has always been against immigration (for racist or economic reasons) and has not been able to distinguish refugees from that flow, or to appreciate Canada's international commitments towards them. Such opinions have been augmented - as they have been elsewhere in the world - by a growing climate of neo-conservatism focused in the Reform Party of Canada which has, through its statements connecting immigrants with job loss, abuse of welfare support and growing levels of crime, encouraged an overt anti-immigration policy to become widely articulated.

These three main strands have caused public opinion, traditionally anti-immigrant but prorefugee, traditionally pro-environment and prepared to be led by a proactive government on both issues, to become increasingly persuaded of the illegitimacy of refugee claims, indifferent to environmental concerns and to demand government pay more attention to these views. The particular needs of the environmental refugee have no opportunity to be met in such a climate.

Canadian government policy towards environmental refugees has, unlike public opinion, been more consistently antagonistic. To appreciate this, it should be borne in mind that most critics of Canadian immigration and refugee policy have argued that the federal government has always seen immigration as only an economic policy lever (Dirks, 1995). To this end, it has been prepared to be proactive and to lead public opinion in accepting high levels of immigration. However, the corollary of this policy is that those elements of immigration policy - principally refugee and family reunification flows - that are not seen as having an overt economic contribution to make to Canada have been strictly monitored.

Certainly, such a "concept of control" towards refugees on the part of the Canadian government can be demonstrated by illustrations as various as Canada's refusal to sign the 1951 Convention until 1976, by legislation in the late 1980s which restricted refugee admission to Canada (Bills C55 and C84) and by current moves to make even refugee claimants pay a fee of $\$ 1000$ for processing. Even Canada's vaunted opinion of itself as a haven for refugees is critiqued by those who have cogently argued that only a quarter of Canada's refugee and humanitarian admissions since 1945 have actually been Convention refugees, the remaining 75 percent have been chosen more for their economic skills than their asylum needs. In other words, even in the operation of its refugee policy, run overtly to meet Canada's international obligations and peddled to the public as such, the Canadian government has been running a covert economic immigration stream (Nash, 1994: 118-122).

In such a light, it should come as no surprise that environmental refugees stand little chance of government sympathy - since they have neither the compulsion of international obligation nor the attraction of obvious wealth or labour skill for the Canadian economy. The problems of environmental refugees and Convention refugees are 
increasingly being treated as those to which Canada is no longer sensitive and is certainly not prepared to provide any solutions.

The evidence for this argument is abundant and runs from the circumstantial to the incontrovertible. Thus, for example, the federal government has made no effort to distinguish between immigrants and refugees in its new policy on processing fees and has sought to engage in a debate on the declining (economic) "quality of immigrants" over recent years. The federal advisory board on immigration has been closed, and academic research on the economic contribution of refugees receives scant attention in public pronouncements of the current minister of immigration - who prefers, instead, to preside over further reductions in refugee levels while business immigration is increased. All of this has occurred at a time when recent federal budget cuts have led to considerable cuts in Canada's overseas aid, and thus in its ability to meet the problems of root causes of refugee flows.

What is incontrovertible, and perhaps chilling, is that the federal government at the highest level has been appraised of the problems of environmental refugees and has recognized that this will be an issue much larger than many imagine in the future, the dimensions of which its advisors already have sensed. Thus, the Intelligence Advisory Committee in a confidential Canadian Intelligence Estimate report to the Cabinet, leaked to the national news agency, the Canadian Press, noted that nearly all the world's environmental problems will have major effects on Canada, foresaw major ecological disaster or North-South conflicts over the issue and concluded that

Canada can expect to have increasing numbers of environmental refugees requesting immigration to Canada, while regional movements of the population at home, such as from idle fishing areas, will add further to population stresses within the country (quoted in Mooney, 1991: A2).

Yet, despite these conclusions, in the eight years that have elapsed since then, the government has had nothing to say with regard to responsible, sensitive solutions to this problem. Moreover, as we learn from elsewhere, Canada is not even prepared to consider broadening the international definition of refugee because, according to a spokesperson for Bernard Valcourt, the then Minister of Immigration, "if the refugee definition is drawn too broadly, we risk defining the problem into complete unmanageability" (quoted in Oziewicz, 1991).

In short, the Canadian government, from its highest levels downwards, is not prepared to act in any way to ease the plight of the environmental refugee. Perhaps even more shocking than this is the realization that this position is one reached not through negligence or omission, but through deliberation and commission. Such, as any student of refugee affairs must concur, is to be expected in the realpolitik of the asylum-seekers' world, but it is troubling to find it expressed by a nation that once was awarded the Nansen Medal for its support of the refugee.

Such an attitude is, however, entirely in keeping with Canada's true traditional response to refugees of all stripes - its attempt to minimize and control the number admitted. That the Cabinet should have been advised to be wary of the threat that environmental refugees pose to its long-run policies of tight control should not therefore be at all surprising.

What is of interest is that now the "concept of control", which has been the dominating government paradigm towards refugees, has diffused throughout the bureaucracy and has begun to appear in the public domain. Whether this diffusion has been spontaneous and a general product of the times or (as some critics allege) an outcome of deliberate government manipulation of public opinion is hard to say at this stage without further research.

However caused, the general decline in the public's receptiveness to refugees, as argued earlier, has happened at the very time that public interest in environmental issues has also waned. This has meant that the problems of the environmental refugee stand little chance of receiving sympathetic public attention at this time.

This conjunction of both government and public opinion is certainly an unusual one for, on other occasions regarding immigration issues, the 
government has shown that it is fully prepared to preside over large increases in immigration to Canada, often in the face of strong public opposition. However, it would be naive not to realize that these situations only apply where the government is convinced of the economic benefits of migration. When the public and the government are of one mind, at least insofar as refugee issues are concerned - then the government has shown itself content not to be proactive.

Two major conclusions emerge from this discussion and apply, it is argued, not only to Canada but to almost every other Western country of resettlement, since Canada's behaviour in this regard, as in so many others regarding immigration and refugee policy, is by no means atypical. The loci of policy formation - and the place where those who seek to agitate on behalf of the environmental refugee undoubtedly lie in both of the two realms we have examined: those of public opinion and government behaviour. Therefore, the removal of impediments to action must operate in both those sectors.

Public opinion needs to be forcefully and urgently reminded, through greater education and lobbying, that Canada - in conjunction with the other nations of the West - may successfully continue to avoid the consequences of its immigration strategies of avoidance and exclusion. However, in the case of environmental refugees, as we have seen in this paper, this can only ever be a vain hope. Their current plight is intimately connected with our future predicament; and, if only because of this, their plight has to be faced.

Perhaps, the most important opinions to change would seem to be those of the bureaucrats responsible for immigration and refugee affairs. As we have seen in Canada recently, ruling political parties come and go, and ministers of immigration are changed regularly. Public opinion on immigration issues is sometimes moulded and often ignored by such governments; however, in this regard, the advice of Canada's deputy-ministers and directorgenerals remains the one true constant (Hawkins, 1989; Dirks, 1995). The guidance of civil servants, at least insofar as refugee issues, has been the paradigm of control - and it is that conception which must be altered if the major impediment to implementing policies favourable to the plight of the environmental refugee is to be removed.

\section{References}

Adelman, H. (1988) 'Obligation and refugees', in Nash, A.E. (ed.) Human Rights and the Protection of Refugees under International Law, Ottawa and Montreal, Institute for Research on Public Policy \& The Canadian Human Rights Foundation, pp. 73-92.

Adelman, H. (1991a) 'Refuge or asylum: a philosophical perspective', in Adelman, H. and Lanphier, C.M. (eds.) Refuge or Asylum: A Choice for Canada, York (Ontario), York Lanes Press, pp. 12-26.

Adelman, H. (1991b) 'Canadian refugee policy in the postwar period: An analysis', in Adelman, H. (ed.) Refugee Policy: Canada and the United States, York (Ontario), York Lanes Press, pp. 172-223.

Canada Employment and Immigration Advisory Council (1991) Immigration in the 1990s, Ottawa, Canada Employment and Immigration Advisory Council.

Canadian Habitat Secretariat (1976) Human Settlement in Canada, Ottawa, Urban Affairs Canada.

Dirks, G.E. (1977) Canada's Refugee Policy: Indifference or Opportunism?, Montreal, McGill-Queen's University Press.

Dirks, G.E. (1995) Controversy and Complexity: Canadian Immigration Policy during the 1980s, Montreal, McGillQueen's University Press.

Employment and Immigration Canada (1982) Indochinese Refugees: The Canadian Response, 1979 and 1980, Ottawa, Minister of Supply and Services.

Employment and Immigration Canada (1987a) Refugee and Humanitarian Programes, December 31, 1986, Ottawa, Minister of Supply and Services.

Employment and Immigration Canada (1987b) Refugee Perspectives, 1987-1988, Ottawa, Minister of Supply and Services.

Environment Canada (1990) Canada's Green Plan, Ottawa, Minister of Supply and Services.

Fincher, R. (1994) 'Environmental claims about the impacts of immigration' in Adelman, H., Borowski, A., Burstein, M. and Foster, L. (eds.) Immigration and Refugee Policy: Australia and Canada Compared (Vol. 2), Toronto: University of Toronto Press, pp. 488-512.

Goodwin-Gill, G. (1991) 'International law and the search for solutions to the refugee problem' in Adelman, $\mathrm{H}$. and Lanphier, C.M. (eds.) Refuge or Asylum: A Choice for Canada, York (Ontario), York Lanes Press, pp. 27-42.

Greenspon, E. (1995) 'Copps bolstered by report calling for more environmental action' The Globe and Mail, Toronto, 21 June, A4.

Grubb, M. (1990) Energy Policies and the Greenhouse EffectVol. 1: Policy Appraisal, Aldershot, The Royal Institute of International Affairs \& Dartmouth Publishing Company.

Hathaway, J.C. (1988) 'Selective concern: An overview of refugee law in Canada', McGill Law Journal, 33: 676-715.

Hathaway, J.C. (1991) The Law of Refugee Status, Toronto, Butterworths.

Hawkins, F. (1989) Critical Years in Immigration: Canada and Australia Compared, Montreal, McGill-Queen's University Press. 
Jacobson, J.J. (1988) Environmental Refugees: A Yardstick of Habitability, Washington D.C., Worldwatch Institute.

Karan, P.P. (1987) 'Environment and Development in Bhutan' Geografiska Annaler, 69B: 15-26.

Kritz, M. (1990) 'Climate Change and Migration Adaptations', Working Paper 2.16, Ithaca: Cornell University, Department of Rural Sociology, Population and Development Program.

MacNeill, J., Winsemius, P. and Yakushiji, T. (1991) Beyond Interdependence, New York, Oxford University Press.

McGregor, J. (1993) 'Refugees and the environment' in Black, R. and Robinson, V. (eds.) Geography and Refugees: Patterns and Processes of Change, London and New York, Belhaven Press, pp. 157-170.

Mooney, P. (1991) 'Third World disaster foreseen: report warns of new refugees' The Globe and Mail, Toronto, 24 June, A1-A2.

Nash, A.E. (1989) International Refugee Pressures and the Canadian Public Policy Response, Ottawa, Institute for Research on Public Policy.

Nash, A.E. (1994) 'Canadian Refugee Policy Into the 1990s' Migration, 21/22: 111-136.

Oziewicz, E. (1991) 'Canada objects to redefining refugees' The Globe and Mail, Toronto, 8 October, A5.

Rawls, J. (1971) A Theory of Justice, Cambridge (Mass.), Belknap Press.

Regier, H.A. and Bales, A.G. (1991) Environmental Impacts of Immigration: A Preliminary Examination, Ottawa, Employment and Immigration Canada.

Richmond, A.H. (1994) Global Apartheid: Refugees, Racism and the New World Order, Toronto, Oxford University Press.
Rizvi, Z. (1988) 'Causes of the refugee problem and the international response' in Nash, A.E. (ed.) Human Rights and the Protection of Refugees under International Law, Ottawa and Montreal, Institute for Research on Public Policy \& The Canadian Human Rights Foundation, pp. 107-120.

Starke, L. (1990) Signs of Hope, Oxford, Oxford University Press.

United Nations (1983) Convention and Protocol Relating to the Status of Refugees, Geneva, Office of the United Nations High Commissioner for Refugees (UN Document HCR/1P/10/ ENG).

United Nations (1986) 'Report of the Group of Governmental Experts on International Co-operation to Avert New Flows of Refugees', New York, United Nations (UN Document A/41/324).

United Nations High Commissioner for Refugees (1984) 'UNHCR: World Refugee Map' Refugees, 12: 24-25.

United Nations High Commissioner for Refugees (1993) The State of The World's Refugees: The Challenge of Protection, Harmondsworth, Penguin.

Walzer, M. (1983) Spheres of Justice, A Defence of Pluralism, New York, Basic Books.

World Commission on Environment and Development (1987) Our Common Future, Oxford, Oxford University Press.

Zero Population Growth (1991) Canadian Population and Immigration, Population and Environment Issue Sheet (version 1.0), Ajax (Ontario), Zero Population Growth of Canada Inc. 


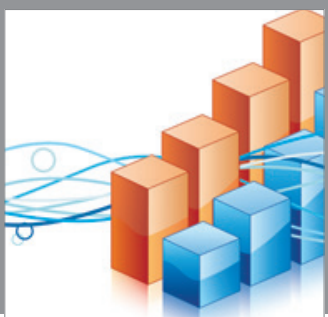

Advances in

Operations Research

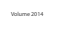

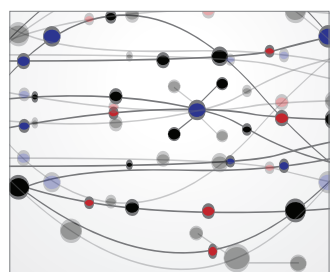

\section{The Scientific} World Journal
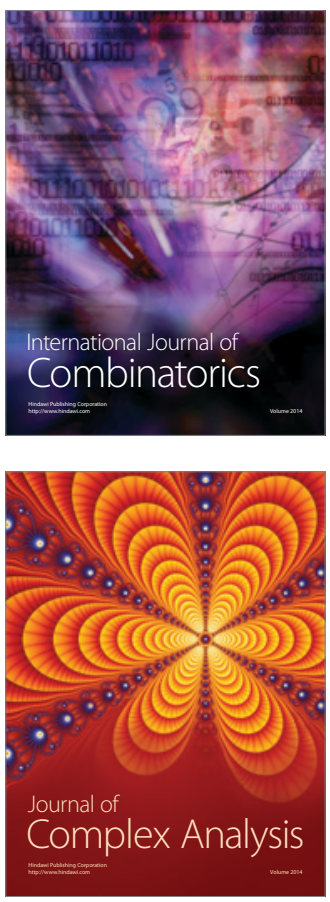

International Journal of

Mathematics and

Mathematical

Sciences
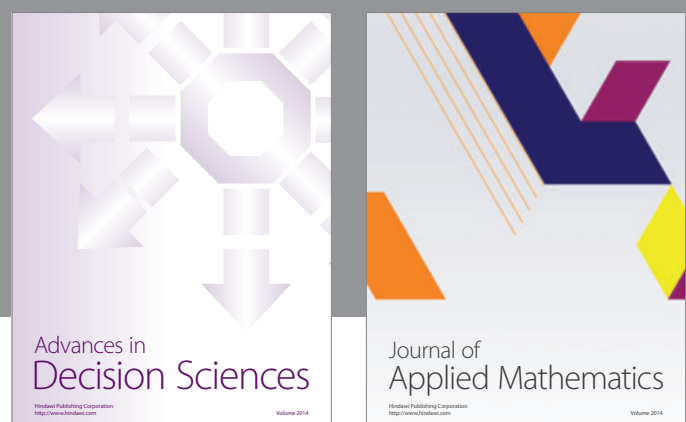

Journal of

Applied Mathematics
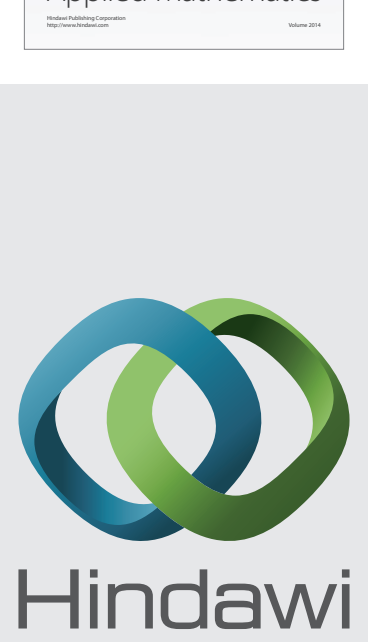

Submit your manuscripts at http://www.hindawi.com
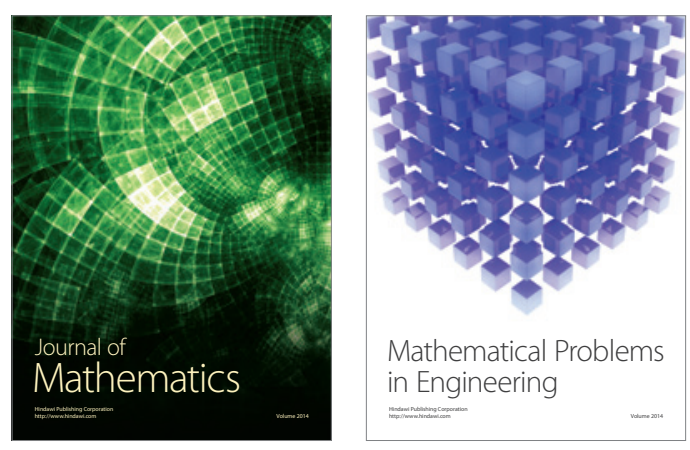

Mathematical Problems in Engineering
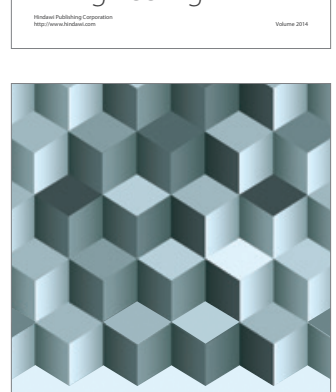

Journal of

Function Spaces
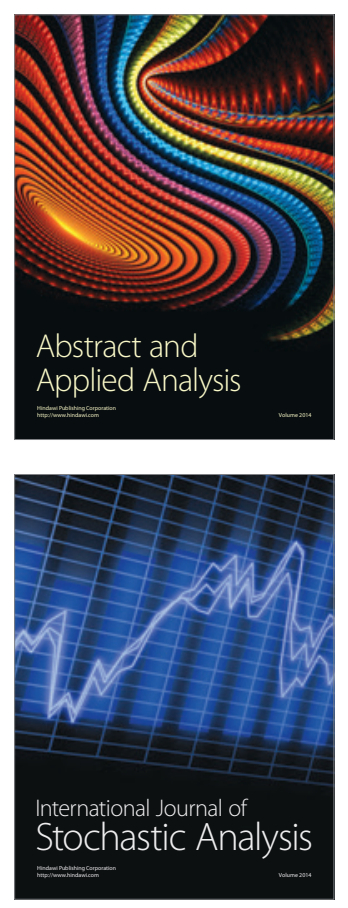

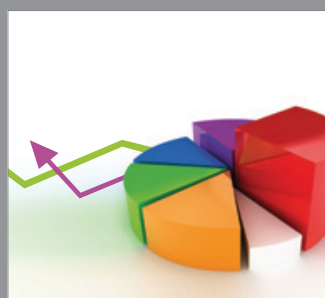

ournal of

Probability and Statistics

Promensencen
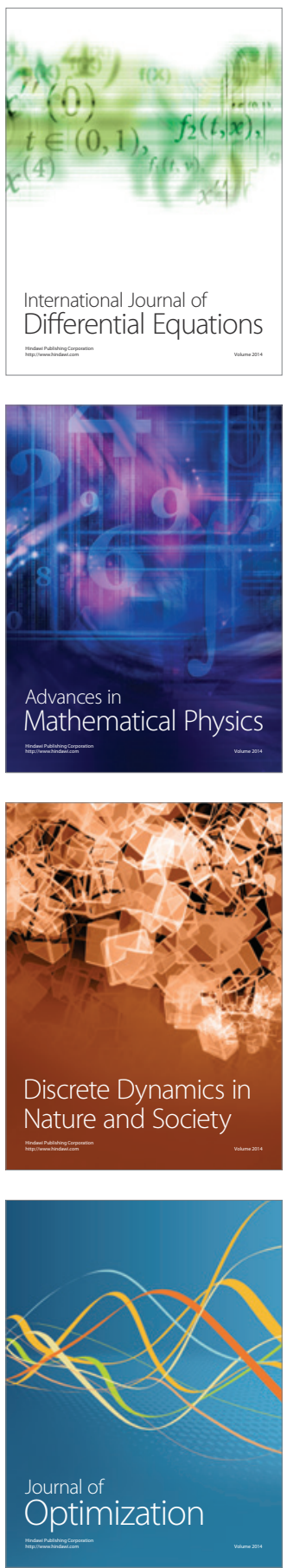